\section{KULTUM DI MESJID BESAR NURUL JIHAD KELURAHAN BONTOTANGNGA KEC. TAMALATEA}

Oleh :

\author{
ALFIRA SAHAR
}

19203770410002

\section{Alfira.sahar0505@gmail.com}

\section{Bentuk kegiatan}

- Kultum

\section{Lokasi}

Mesjid Besar Nurul Jihad Kelurahan Bonto Tangnga Kec.Tamalatea

\section{Hari/Tanggal dan Waktu}

Selasa, 06 Oktober 2020 pukul 04:00 -05:20

\section{Peserta yang dilibatkan}

\section{Mahasiswa KKLP}

\section{Alasan diadakannya}

Kegiatan kultum ini dilaksanakan karena mengingat saling mengingatkan dalam kebaikan dan kebenaran adalah kewajiban bagi semua umat manusia.

\section{Tujuan dan manfaat}

memberikan motivasi kepada masyarakat bonto tangnga serta mahasiswa kklp itu sendiri karena berbagi bahagiaan tertinggi adalah ketika kita bisa berbagi ilmu dengan orang-orang di sekitar kita .

\section{Deskripsi kegiatan}

kegiatan kultum ini merupakan kegiatan yang sangat positif bagi kami dalam proses kultum ini yang dilaksanakan pada subuh hari mengharuskan kami untuk bangun lebih awal serta masyarakat begitu antusias dengan adanya proker yang langka seperti ini 